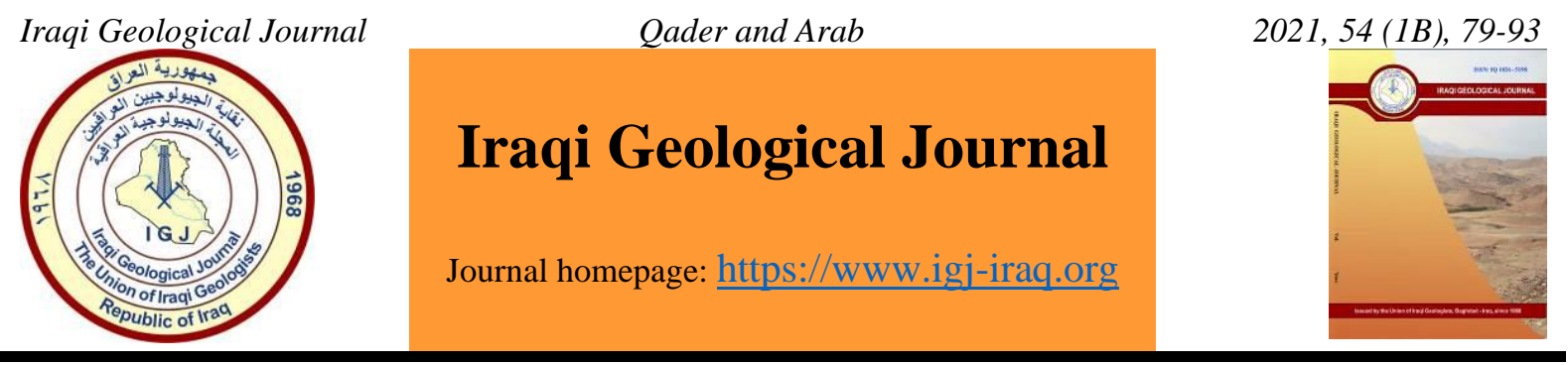

\title{
Rock Slope Stability Assessment Along Rawanduz Main Road, Kurdistan Region
}

\author{
Rebaz Muhammed Qader ${ }^{1, *}$ and Soran Hasan Arab Syan ${ }^{1}$ \\ ${ }^{1}$ Department of Geology, College of Science, Salahaddin University, Erbil, Iraq \\ *Correspondence: rebaz_qader@yahoo.com
}

Received: 3 July 2020; Accepted: 20 December 2020; Published :28 February 2021

\begin{abstract}
The rock slope instability along the Khalifan-Bekhal-Rawanduz main road has been studied in the southwestern limb of the Bradost anticline (Mountain) and both northeastern and southwestern limb of the Korek anticline (Mountain) in northeast of the Erbil city, Kurdistan Region, Iraq. The major factors of the instability of the rock slopes in the study area are types of discontinuous and the degree of erosion. Ten stations have been chosen for fieldwork. The expected failure types that may occur along the road are plane sliding and wedge sliding. This research is mainly focused on the type of failure along the rock slope and the factor that affect the instability of the studied slopes and have found that they are slope orientation and geometry of the discontinuity. Different remediation methods are proposed for the studied rock slopes base on rock slope analysis. The rock slopes along the road require continuous monitoring because of their hazard conditions.
\end{abstract}

Keywords: Slope stability; Landslide; Rock slope; Rwanduz; Kurdistan

\section{Introduction}

Evaluation of the stability slope along and around the road is a necessary assignment due to their effect on human life as well as properties. The study area lies nearly $110 \mathrm{~km}$ northeast of Erbil city and is located in the Korek and Bradost anticlines in Kurdistan Region, Iraq. Some localities in the SW limb of Bradost anticline and both SW and NE limbs of the Korek anticline were chosen for this research because the main road was included. In addition, the stability problem of the rock slopes along the road in the study area is a major concern in most places because the rock sliding directly affects human lives and traffic activities. The material characteristics of a rock slope, the height, the face angle, and the discontinuity orientations play a great role in the instability problem of road and slopes (Hoek and Bray, 1981). The rock sliding is active in the SW limb of Bradost and the NE limb of the Korek anticline. Furthermore, preventing the approaching rock sliding is the main significant fact. Most of the previous studies on the selected road are found in different geological subjects (sedimentological, stratigraphic, hydrological and geomorphological subjects). Ten stations were selected for evaluating the stability along the Khalifan-Bekhal-Rawanduz main road. Stereonet projection technique is commonly used to predict potential failure zone (plane and wedge sliding) and the possible direction of failure movement (Hoek and Bray, 1981; Hudson and Harrison, 1997; Norrish and Wyllie, 1996; Wyllie and Mah, 2004). The recent failures on the road have already been recorded. The aim of this research is to determine the failure mode in the studied rock slopes, in addition, explaining the factors that affected the stability of DOI: 10.46717 /igj.54.1B.7Ms-2021-02-25 
the rock slopes to delineate the unstable zone and proposing the remediation method for stabilizing the slopes and protecting the road. The aim of this study are field attitude measurements for rock slopes and discontinuities, also their classification according to the attitude of layers and their tectonostratigraphy, moreover, constructing stereonet projection diagram for field attitude measurements, identifying the potential failure zone movement, determining rock strength, calculating friction angle for the rock and describing the rock slope properties.

\section{The Study Area}

Khalifan - Bekhal - Rawanduz road has been chosen for this study, this road started from Khalifan area, it is a town located in Iraqi Kurdistan's Erbil Province, near Soran. It is located $80 \mathrm{~km}$ northeast of Erbil city and the road ended in Rawanduz district area, it is located $10 \mathrm{~km}$ to the east from Bekhal Waterfall. The Rawanduz district is $123 \mathrm{~km}$ from Erbil city. Khalifan - Bekhal - Rawanduz road constructed in the Southwest limb of Bradost Mountain and Northeast to Southwest limb of the Korek Mountain. This road is the major road that connects Khalifan town with Rawanduz district area. In addition, the study area is bordered by latitudes: $36^{\circ} 37^{\prime} 01^{\prime \prime}-36^{\circ} 37^{\prime} 07^{\prime \prime} \mathrm{N}$ and longitudes: $44^{\circ} 29^{\prime}$ $46^{\prime \prime}-44^{\circ} 25^{\prime} 03^{\prime \prime}$ E (Fig. 1).

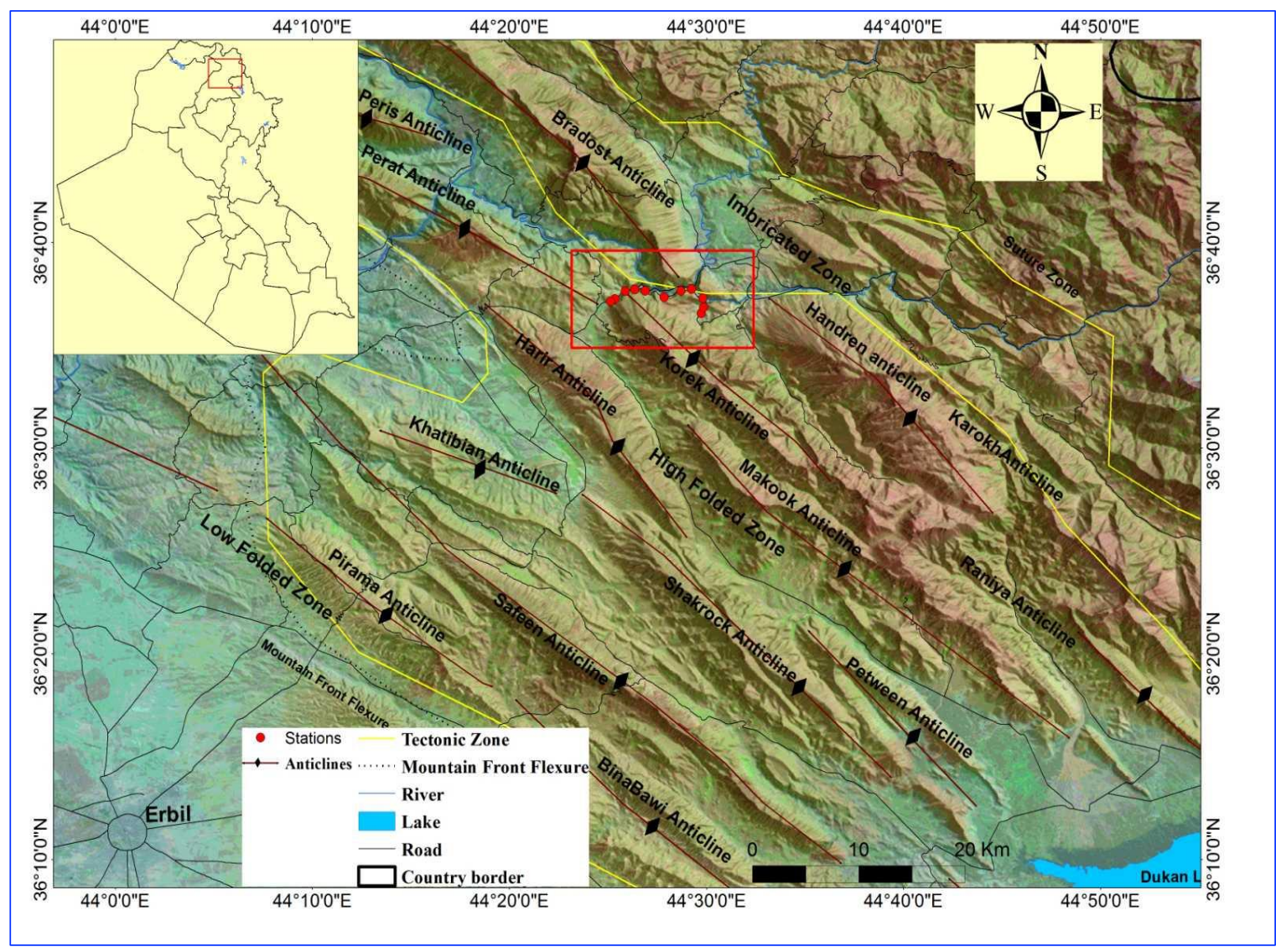

Fig. 1. Digital Elevation Model (DEM) of the NE part of the Iraqi Kurdistan Region showing the study area and the slope stations along the Khalifan - Bekhal - Rawanduz main road

\subsection{Khalifan - Bekhal - Rawanduz Road - Historical Background}

Since the construction of Rawanduz main road along the section Khalifan-Bekhal-Rawanduz road many incidents have occurred. The major rock slides took place in the winter season due to high rain and snow in these mountain areas which caused losses of property and blocking the road. Removing the rocks and debris at the toe of the slope and the road is the only measures that taken by the Rawanduz 
governorate road department. During the field work the rock sliding occurred and that is indicated to the hazards of many slope sites along the road.

\section{Geological Setting}

The geological setting of the studied area; including tectonics, structural geology and stratigraphy of the study area which are described briefly;

\subsection{Tectonics}

The Arabian Plate as a part of young, active Zagros orogeny has a complex tectonic history, which comprises passive and active margin (Buday and Jassim, 1987). Zagros mountain orogeny process recognized as a collisional belt with $2000 \mathrm{~km}$ length, started in SE - Turkey to Kurdistan Region of Iraq (KRI) then East - Iraq and depression direction to Strait of Hormuz and Oman mountains in SE part of the belt (Mouthereau et al., 2012). The study area which comprises Korek and Bradost anticlines is a portion of Zagros Fold-Thrust Belt and northern Iraq, it is located in the northeastern side of the Arabian Plate. The Zagros Fold Thrust Belt (ZFTB) in the KRI is subdivided into five tectonic zones (Fouad, 2010; Jassim and Buday, 2006). These tectonic regions from the hinterland (NE) to the foreland (SW) are Zagros Suture Zone (ZSZ), Imbricate Zone (IZ), High Folded Zone (HFZ), Foothill Zone and Mesopotamian Foreland Basin. Bradost Anticline located within an (IZ) while Korek Anticline situated within the (HFZ) their geometry direction (NW-SE) is parallel to the Zagros orogeny belt (Fouad, 2010).

\subsection{Geological Structures}

The study area with a point view of geological structure located in the both Bradost and Korek anticlines. In addition, Korek Anticline that is located within the High folded zone of the Zagros Fold and Thrust Belt in the Northern Iraq-Kurdistan region (Omer and Othman, 2018) and According to Omar, (2005), the Bradost anticline located in the Imbricated Zone (IZ) between the Zagros suture units and the Zagros Fault Thrust Belt (ZFTB). Both anticlines are described briefly as follow:

\subsubsection{Bradost Anticline}

The Bradost Anticline structure is a relatively long $(\sim 55 \mathrm{~km})$ and wide (6 to $9.5 \mathrm{~km})$ is an asymmetrical anticline with double plunging, the southeastern plunge of Bradost anticline is interfering with Korek and Handrin anticlines, while in the northwest plunged near the southeast of the Barzan area in Rukuchk river and interfering with Shirin anticline (Balaki and Omar, 2019). The southeastern part of the Bradost thrusted anticline is a great concern because contains of six NW-SE-directed main thrusts (Balaki and Omar, 2019). Balaki and Omar (2019) believed that the Bradost Anticline structure is comprises combination of two different geometries and styles and divided by minor Syncline.

\subsubsection{Korek Anticline}

The Korek Anticlinal is asymmetrical double plunging. The Korek Anticline is $\sim 32 \mathrm{~km}$ long and $\sim 5.6 \mathrm{~km}$ wide as measured from satellite image (Omar and Othman, 2017). The vergency of the anticline shows different directions, in some parts it is verged toward northeast while in some other parts verged toward southwest and numerous faults affected the NE and SW limbs of the anticline, also the Cretaceous Formations dictate the shape of the anticline (Omar and Othman, 2017). The NW-SE limb of the Korek Anticline is composed of Jurassic Formations, whereas the trough lithology of Syncline is a late Cretaceous Formation (Fig. 2). 


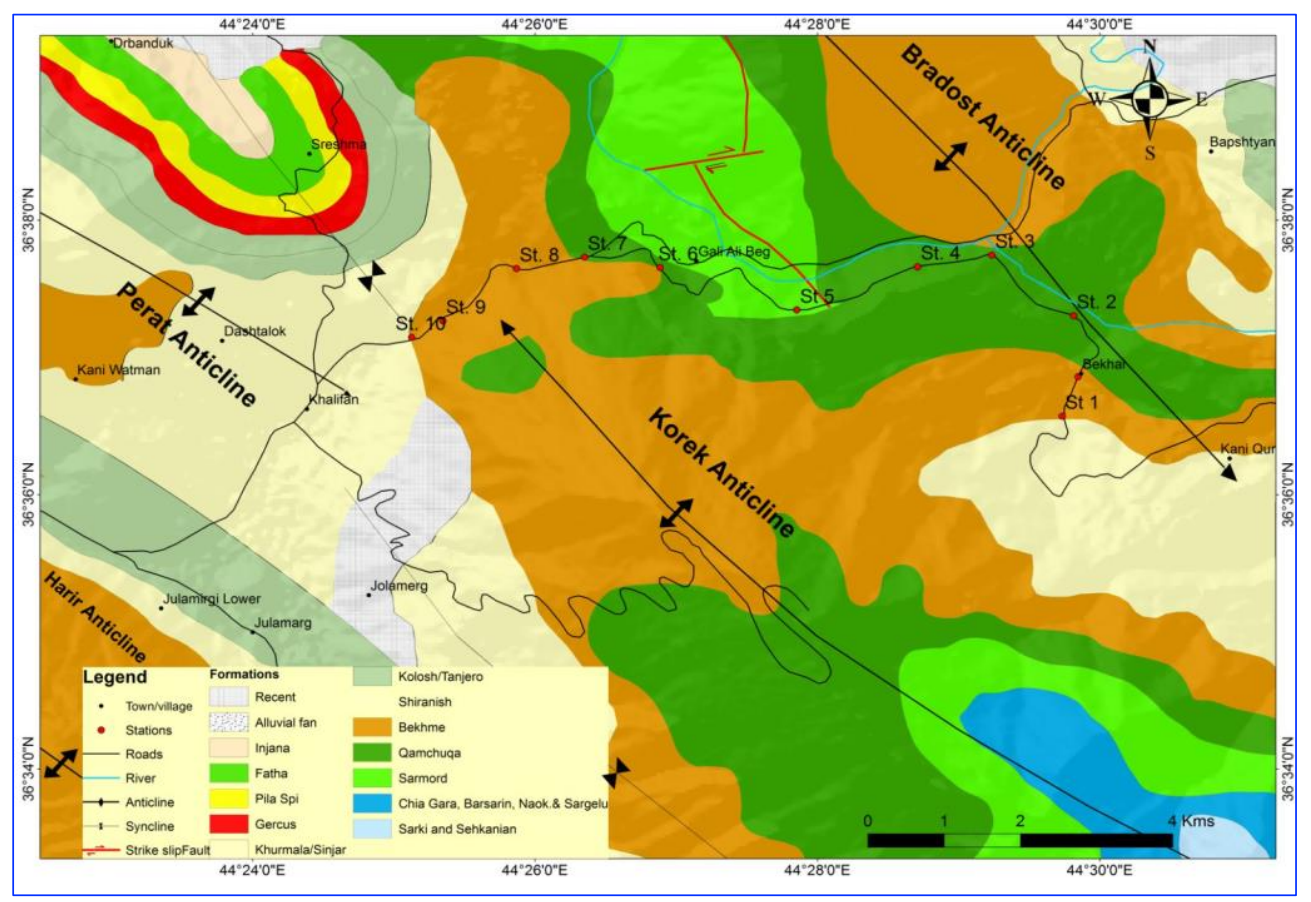

Fig. 2. Structural and geological map of the study area showing the location of the selected slopes stations (Balaki and Omar, 2019)

\subsection{Stratigraphy}

The sedimentary cover in the (HFZ) consists of competent successions with relatively few incompetent beds, furthermore, sediment cover ranges between 5-11 km, with an average of 8-10 in regular at NW block of the HFZ (Sissakian and Al-Jiburi, 2014). The Arabian Plate is divided into eleven tectonostratigraphic megasequences separated by major unconformities (Sharland et al., 2001). The sedimentary rocks of the HFZ consist of Infracambrian rocks, Palaeozoic (1.5-5 km), Triassic (1.5$2 \mathrm{~km})$, Jurassic $(1.1 \mathrm{~km})$, Lower Cretaceous $(0.25-1.2 \mathrm{~km})$, Late Cretaceous $(0.8 \mathrm{~km})$ and Palaeogene (1-1.5 km) sediments, Neogene sediments found only locally in some Synclines (Sissakian and AlJiburi, 2014; Jassim and Buday, 2006). The exposed geological Formations in the stations deposited during Lower to Upper Cretaceous periods, which are represented by Sarmord/Balambo, Qamchuqa and Bekhme formations. These mechanically competent Formations are dominated by limestone, dolomite, dolomitic limestone, and marly limestone. The Formations are explained briefly from younger to older as shows in Fig. 2.

\subsubsection{Bekhme Formation}

This Formation recognized at the Bekhme Gorge of the Greater Zab River in NE Iraq (Sissakian and Al-Jiburi, 2014; Jassim and Goff, 2006). The Behkme Formation belongs to the Late CampanianEarly Masstrichtian cycle (Amer, 1993). It is exposed in Korek, Bradost Anticline and other anticlines in the HFZ in addition the Bekhme Formation, mostly composed of limestone and dolomite (Sissakian and Al-Jiburi, 2014). The limestone is light gray and grayish brown in color, hard, thick bedded to massive. Lower part well bedded, composed of conglomerate and bituminous materials. The middle unit is composed of reefal limestone, thickly bedded, but the upper part is the thickest unit that composed of very hard dolomite and contains large rudist debris (Sissakian and Youkhanna, 1979). It is conformably underlying the Shiranish Formation, and unconformably overlying the Qumchuqa Formation (Sissakian and Al-Jiburi, 2014). 


\subsubsection{Qamchuqa Formation}

This Formation is presented by Wetzel, 1950 from the Qamchuqa Gorge in NE Iraq (Sissakian and Al-Jiburi, 2014). Al-Shwaily et al. (2012) claimed an Early Cretaceous age (Early Aptian - Early Cenomanian) for the Formation. It is exposed in the both limbs at the Northwestern plunge of Korek Anticline which had dissected by the Rawanduz river. It is also exposed in the core of the Bradost Anticline (Balaki and Omar, 2019). This formation mostly composed of hard rock to very solid rock, well bedded to massive, fractured dolomite and argillaceous limestones, brown in color to grayish brown, moreover, different types of carbonate rocks were observed such as dolomitic, crystalline, organic, bituminous and fossiliferous (Sissakian and Al-Jiburi, 2014). The underlying contact is conformable and gradational with the marl-dominated Sarmord/Balambo Formation (Mamaseni et al., 2019).

\subsubsection{Sarmord/Balambo Formation}

The name of this formation is derived from two Formations, namely Sarmord and Balambo (Sissakian and Al-Jiburi, 2014). Al-Shwaily et al. (2012) proposed that in some areas of northern Iraq due to intertonging between these two Formations, it is impossible to differentiate between them, especially around Rawanduz area. Sarmord Formation belongs to the Early Cretaceous age, additionally, the contact between this Sarmord/Balambo Formation and Chia Gara Formation is gradational (Karim and Khanaqa, 2016). This Formation appears in different localities within the studied areas, at the core of the Korek Anticline (Omar and Othman, 2017) and SW limb of the Bradost Anticline (Balaki and Omar, 2019). This Formation in the studied area in the lower to upper parts composed of gray, thick bedded marl interbedded with yellow, medium bedded marly limestone, sometimes argillaceous, with blue gray calcareous shale starts with friable, weak, gray bedded of shale which are rich in organic (Mamaseni et al., 2019).

\section{Materials and Methods}

\subsection{Slope Stability Assessment}

In this work, ten stations have been chosen for assessing the slope stability. Stations (1 to 4) located within Bradost Anticline while the other stations located within Korek Anticline (Fig. 2). The rock slopes and the rock mass with their discontinuities (bedding planes and joints) were surveyed at each station, the attitude is measured by using a Brunton compass to determine the (strike, dip angle and dip direction (strike $+90^{\circ}$ ), persistence, spacing and frequency of the discontinuities. The recorded data used for making the stereographic projection diagram by using Stereonet 8 Software (Allmendinger et al., 2012). The Laboratory analysis was also done to evaluate the strength index from the point load test as per suggested method (ISRM, 1985). The friction angle of discontinuity failure surfaces was determined by performing the tilting method (Bruce et al., 1989). Also, the failure types were identified according to the relationship between attitudes of the discontinuities and rock slope according to (Hoek and Bray, 1981; Hudson and Harrison, 1997; Norrish and Wyllie, 1996; Wyllie and Mah, 2004) classification. According to the Al-Saadi's classification (1981), the rock slopes were classified. AlSaadi's classification of the rock slope based on the three parameters, Firstly Divergent angle (d), the slope is parallel if the divergent angle (d) from slope face trend and strike of the layers does not reach to $20^{\circ}$. They are oblique lateral if $\mathrm{d}$ between $20^{\circ}$ to $70^{\circ}$ and orthogonal if $\mathrm{d}$ between $70^{\circ}$ to $90^{\circ}$. Secondly, laterality it is the emergence of the strike of the layer to the lateral side left or right of the observer who faces the slopes. Finally, concordance the slopes are concordant if the dipping of layer and the slope inclination are in the same direction. Engineering description of the rock mass along the slope based on 
the Anon (1972; 1977) and Hawkins (1986). The point load test was carried out on the dolomitic limestone and limestone samples which were collected at the stations.

\subsection{Results and Discussion}

In order to assess the stability along the slope, a number of sites was chosen and at all of them, the rock slope and discontinuities (bedding planes and joints) attitude were measured using by Brunton compass to determine the strike, dip angle and dip direction that is given in Table 2, the data at each site applied to make a stereographic projection by using Stereonet 8 Software (Allmendinger et al. 2012). Also, the The friction angle of discontinuity failure surfaces was determined by performing the tilting method which is equal to $30^{\circ}$ as a mean value (Bruce et al. 1989). According to Hoek and Bray (1981; Hudson and Harrison (1997); Norrish and Wyllie (1996); Wyllie and Mah (2004) classification, types of failure are determined for all stations based on the relationship between attitudes of the bedding plane, joints and rock slope. Table 1 shows the strength of the rock sample base on the point load test (ISRM, 1985). Moreover, the description of the rock mass for each station along the road in the study area is described below (Anon, 1972; 1977; Hawkins, 1986). The rock slopes classified according to Al-Saadi's (1981). Moreover, the description of the rock mass for each station in the study area is described below.

Table 1. Results of point load and unconfined compressive strength $(\sigma c)$ tests for the collected specimens of the dolomitic limestone and limestone lithology in the study area

\begin{tabular}{|c|c|c|c|c|c|c|c|c|}
\hline 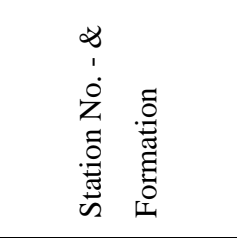 & 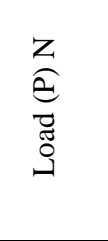 & 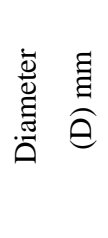 & 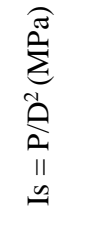 & 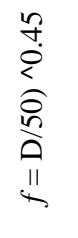 & 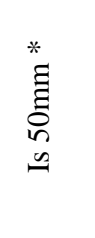 & 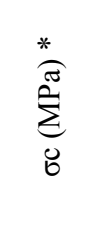 & 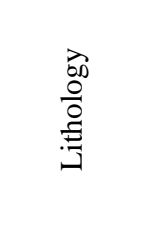 & 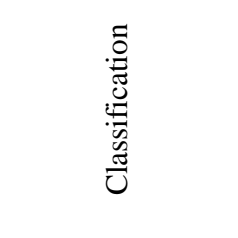 \\
\hline 1-Bekhme Fm. & 45200 & 84 & 6.41 & 1.26 & 8.09 & 182.03 & $\begin{array}{l}\text { Dolomitic } \\
\text { Limestone }\end{array}$ & Very Strong \\
\hline 2-Qamchuqa Fm. & 33600 & 45 & 16.59 & 0.95 & 15.82 & 356.05 & Limestone & Extremely Strong \\
\hline 3-Sarmord Fm. & 40700 & 71 & 8.07 & 1.17 & 9.45 & 212.71 & Limestone & Extremely Strong \\
\hline 4-Qamchuqa Fm. & 66900 & 81 & 10.20 & 1.24 & 12.67 & 285.05 & $\begin{array}{l}\text { Dolomitic } \\
\text { Limestone }\end{array}$ & Extremely Strong \\
\hline 5-Qamchuqa Fm. & 15500 & 87 & 2.05 & 1.28 & 2.63 & 59.12 & $\begin{array}{l}\text { Dolomitic } \\
\text { Limestone }\end{array}$ & Strong \\
\hline 6-Qamchuqa Fm. & 25700 & 68 & 5.56 & 1.15 & 6.38 & 143.61 & $\begin{array}{l}\text { Dolomitic } \\
\text { Limestone }\end{array}$ & Very Strong \\
\hline 7-Qamchuqa Fm. & 26900 & 106 & 2.39 & 1.40 & 3.36 & 75.54 & Limestone & Strong \\
\hline 8-Bekhme Fm. & 20800 & 49 & 8.66 & 0.99 & 8.58 & 193.15 & Limestone & Very Strong \\
\hline 9-Bekhme Fm. & 28500 & 84 & 4.04 & 1.26 & 5.10 & 114.78 & $\begin{array}{l}\text { Dolomitic } \\
\text { Limestone }\end{array}$ & Very Strong \\
\hline 10-Bekhme Fm. & 24300 & 69 & 5.10 & 1.16 & 5.90 & 132.75 & $\begin{array}{l}\text { Dolomitic } \\
\text { Limestone }\end{array}$ & Very Strong \\
\hline
\end{tabular}

*Unconfined Compressive Strength $\sigma \mathrm{c}=22.5 *$ Is $(50), \mathrm{Is}=\mathrm{F} *\left(\mathrm{p} / \mathrm{D}^{\wedge} 2\right)$. 
Table 2. Field measurement for rock slopes and discontinuities (bedding planes and joints) of the road

\begin{tabular}{|c|c|c|c|c|c|c|c|c|}
\hline$\stackrel{0}{\stackrel{0}{0}}$ & $\begin{array}{l}\frac{\pi}{2} \\
\stackrel{0}{0} \\
\stackrel{0}{\infty}\end{array}$ & 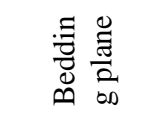 & $\begin{array}{l}\bar{\Xi} \\
\stackrel{\Xi}{0}\end{array}$ & $\stackrel{\stackrel{N}{0}}{\stackrel{0}{0}}$ & $\stackrel{\infty}{\stackrel{0}{0}}$ & $\stackrel{+}{\stackrel{\circ}{\circ}}$ & $\begin{array}{l}n \\
\stackrel{0}{0} \\
\stackrel{0}{\circ}\end{array}$ & $\underset{\dot{m}}{\stackrel{*}{*}}$ \\
\hline 1 & 118/75SW & $113 / 72 \mathrm{SW}$ & $140 / 46 \mathrm{SW}$ & $123 / 89 \mathrm{SW}$ & $99 / 76 \mathrm{SW}$ & - & - & 16 \\
\hline 2 & 021/64SE & $110 / 17 \mathrm{SW}$ & 201/16 NW & $120 / 85 \mathrm{SW}$ & $195 / 78 \mathrm{NW}$ & 086/74SE & 030/34SE & 18 \\
\hline 3 & $263 / 78 \mathrm{NW}$ & 204/16 NW & $125 / 84 \mathrm{SW}$ & 200/89 NW & $235 / 74 \mathrm{NW}$ & $220 / 54 \mathrm{NW}$ & - & 15 \\
\hline 4 & 110/86SW & $224 / 10 \mathrm{NW}$ & $164 / 80 \mathrm{SW}$ & $230 / 83 \mathrm{NW}$ & 200/74 NW & $260 / 88 \mathrm{NW}$ & $324 / 75 \mathrm{NE}$ & 11 \\
\hline 5 & $102 / 87 \mathrm{SW}$ & $185 / 14 \mathrm{NW}$ & $255 / 85 \mathrm{NW}$ & 200/89 NW & 275/90 NE & $230 / 76 \mathrm{NW}$ & - & 12 \\
\hline 6 & $102 / 87 \mathrm{SW}$ & $185 / 17 \mathrm{NW}$ & $165 / 17 \mathrm{SW}$ & $166 / 77 \mathrm{SW}$ & $170 / 90 \mathrm{SW}$ & $240 / 90 \mathrm{NW}$ & - & 14 \\
\hline 7 & 266/74NW & $002 / 24 \mathrm{SE}$ & 268/87 NW & 220/64 NW & $162 / 72 \mathrm{SW}$ & $012 / 86 \mathrm{SE}$ & $220 / 86 \mathrm{NW}$ & 21 \\
\hline 8 & $245 / 77 \mathrm{NW}$ & $214 / 21 \mathrm{NW}$ & $119 / 87 \mathrm{SW}$ & $192 / 51 \mathrm{NW}$ & $125 / 90 \mathrm{SW}$ & - & - & 8 \\
\hline 9 & $260 / 78 \mathrm{NW}$ & $214 / 21 \mathrm{NW}$ & 155/64 SW & 199/12 NW & 240/84 NW & 240/84 NW & $272 / 70 \mathrm{NE}$ & 25 \\
\hline 10 & 103/78SW & $244 / 76 \mathrm{NW}$ & $155 / 85 \mathrm{SW}$ & $170 / 49 \mathrm{SW}$ & $150 / 23 \mathrm{SW}$ & - & - & 25 \\
\hline
\end{tabular}

*S.H.: Slope Height

Along the road, ten stations have been chosen in the study area and the study was carried out in each station as follows:

\subsubsection{Station 1}

It is measured in the southwest limb of the Bradost Mountain at the Bekhme Formation (longitude: $44^{\circ} 29^{\prime} 46^{\prime \prime} \mathrm{E}$ and Latitude: $36^{\circ} 37^{\prime} 01^{\prime \prime} \mathrm{N}$ ) (Fig. 2). The rock slope height, slope and discontinuities (bedding planes and joints) attitude are illustrated in Table 2. According to slope and exposed layers orientation data the slope is parallel because the divergent angle is $5^{\circ}$, but the slope is left emergent in laterality, moreover the slope has a concordance (Al-Saadi's, 1981). The unstable rock block is fractured and parallel to the direction of the slope and $10 \mathrm{~m}$ high and about $3.2 \mathrm{~m}$ wide, in addition the next slab is $3 \mathrm{~m}$ high and $1.3 \mathrm{~m}$ wide (Fig. 3).The unstable rock slab consists of light grey, fine grained, extremely closely jointed, moderately weathered and very strong dolomitic limestone. The dolomitic limestone rock slab has a continuous discontinue with moderate spacing and frequency of 2$3 / 3 \mathrm{~m}$, as a result this different joints has led to release the back side in the first slab and accordingly caused the sliding, also the joints are presented in second rock block with moderately space and average frequency of $7-10 / 3 \mathrm{~m}$. The probable type of failure in this station is a wedge sliding and plane sliding. The wedge sliding in the intersection between (joint 3 and bedding plane), (joint 3 and 1) and (bedding plane and joint1) due to the line of intersection (daylight) to face slopes and it is steeper than the average friction angle of the plane, the plane sliding likely to occur within Joint 3 and bedding plane because the dip direction of the potential sliding plane is within $20^{\circ}$ of dip direction of slope face (Hoek and Bray, 1981; Hudson and Harrison, 1997; Norrish and Wyllie, 1996; Wyllie and Mah, 2004) (Fig. 4).

\subsubsection{Station 2}

The second station is located $250 \mathrm{~m}$ away from station 1. It is placed on the southwest limb of the Bradost Mountain at the Qamchuqa Formation with longitude: $44^{\circ} 29^{\prime} 55^{\prime \prime}$ E and Latitude: $36^{\circ} 37^{\prime} 10^{\prime \prime}$ $\mathrm{N}$ (Fig. 2). The rock slope height, slope and discontinuities (bedding planes and joints) attitude are shown in Table 2. The orientation data of slope and the layers showing that the slope is orthogonal because the divergent angle is $89^{\circ}$, but the slope is right emergent in laterality, also it is discordant (AlSaadi's, 1981). The exposed strata along the slope are mainly fractured and the unstable rock block consists of light grey, fine grained, extremely closely jointed, highly weathered limestone (Fig. 3). The limestone rock block cut by five sets of joints with average spacing is $1.5 \mathrm{~cm}$ and frequency of $12 / 3 \mathrm{~m}$ with extremely closely spaces. The joint sets along the slope release the lateral side of the rock block and it caused the failure. The wedge failure is a probable type of failure that occur at this station at the 
intersection between joint 5 and joint 4 and joint 5 and joint 2 due to the line of intersection (daylight) to face slopes and it is steeper than the average friction angle of the plane, also the plane sliding possible to occur within Joint 5 because the dip direction of the potential sliding plane is within $20^{\circ}$ of dip direction of slope face (Hoek and Bray, 1981; Hudson and Harrison, 1997; Norrish and Wyllie, 1996; Wyllie and Mah, 2004) (Fig. 4).

\subsubsection{Station 3}

The measurement in this station is on the southwest limb of the Bradost Mountain at the Sarmord Formation with longitude: $44^{\circ} 29^{\prime} 30^{\prime \prime}$ E and Latitude: $36^{\circ} 37^{\prime} 30^{\prime \prime} \mathrm{N}$ (Fig. 2). Table 2 explains the rock slope height, slope and discontinuities (bedding planes and joints) attitude. According to slope and exposed layers orientation data the slope is oblique, because the divergent angle is $59^{\circ}$, but the slope is left emergent in laterality, moreover the slope has a concordance (Al-Saadi's, 1981). The exposed strata along the slope are mainly fracture and about 3-4 m thick of the yellowish grey, fine grained, closely jointed, highly weathered and limestone in lithology. The limestone is underlined by fine grain darkly grey marly limestone with widely spaced joint that affected highly by weather. Rock slabs are cut by four joints with average spacing is $2 \mathrm{~cm}$, frequency $8 / 3 \mathrm{~m}$ with, extremely closely spaces and underlined by marly limestone (Fig. 3). The failure that occurs in this rock slope is wedge sliding at the intersection between joint 4 and joint 1 and joint 3 and joint 2 because the plunge of the line of intersection is greater than the friction angle surface (Hoek and Bray, 1981; Hudson and Harrison, 1997; Norrish and Wyllie, 1996; Wyllie and Mah, 2004) (Fig. 4). The Fig. 3 at station 3 showing the recent rock failure.

\subsubsection{Station 4}

The position of the station 4 is the SW limb of the Bradost Anticline at the Qamchuqa Formation with longitude: $44^{\circ} 27^{\prime} 51^{\prime \prime} \mathrm{E}$ and Latitude: $36^{\circ} 37^{\prime} 21^{\prime \prime} \mathrm{N}$ (Fig. 2). The field measurement for rock slope height, slope and discontinuities (bedding planes and joints) attitude demonstrated in Table 2 . The slope and exposed layers orientation data determined that the slope is orthogonal, but the slope is left emergent in laterality, moreover the slope has a discordant (Al-Saadi's, 1981).The exposed strata along the slope are mainly fractured beds which consist of grey to light brown, fine grained, moderately jointed, moderately weathered and dolomitic limestone in lithology (Fig. 3). The dolomitic limestone is arranged in the slope as a block with $5 \times 5 \mathrm{~m}$ dimension in size and affected by five joints with average spacing is $2 \mathrm{~cm}$, frequency $5 / 3 \mathrm{~m}$ and extremely closely spaces, in addition the discontinuities are highly vegetates contains and that makes a favourable force with slope and causing the failure. The wedge sliding is a failure type that occurs in this station at the intersection between joint 2 and joint 3 and joint 3 and joint 4 because the plunge of the line of intersection is greater than the friction angle surface (Hoek and Bray, 1981; Hudson and Harrison, 1997; Norrish and Wyllie, 1996; Wyllie and Mah, 2004) (Fig.4). In Fig. 3 at station 4 illustrates the recent failure in the toe of the slope and their hazard condition.

\subsubsection{Station 5}

This station is located at the northeast limb on Korek Mountain at the Qamchuqa Formation with longitude: $44^{\circ} 26^{\prime} 19^{\prime \prime} \mathrm{E}$ and Latitude: $36^{\circ} 37^{\prime} 43^{\prime \prime} \mathrm{N}$ (Fig. 2). The rock slope height, slope and discontinuities (bedding planes and joints) attitude are illustrated in Table 2. Depending on slope and exposed layers orientation data the slope is orthogonal, left emergent in laterality, moreover the slope has a concordance (Al-Saadi's, 1981). The layers are light brown to grey, fine grained, medium bedded, moderately weathered and strong dolomitic limestone. The dolomitic limestone rock block has four discontinuities and that led to the potential sliding along the bedding plane (Fig. 5). The probable type of failure in this station is a wedge sliding in the intersection between (joint 1 and joint 4 ) due to the line of intersection (daylight) to face slopes and it is steeper than the average friction angle of the plane. The 
plane sliding likely to occur within joint 3 because the dip direction of the potential sliding plane is within $20^{\circ}$ of dip direction of slope face (Hoek and Bray, 1981; Hudson and Harrison, 1997; Norrish and Wyllie, 1996; Wyllie and Mah, 2004) (Fig. 6).

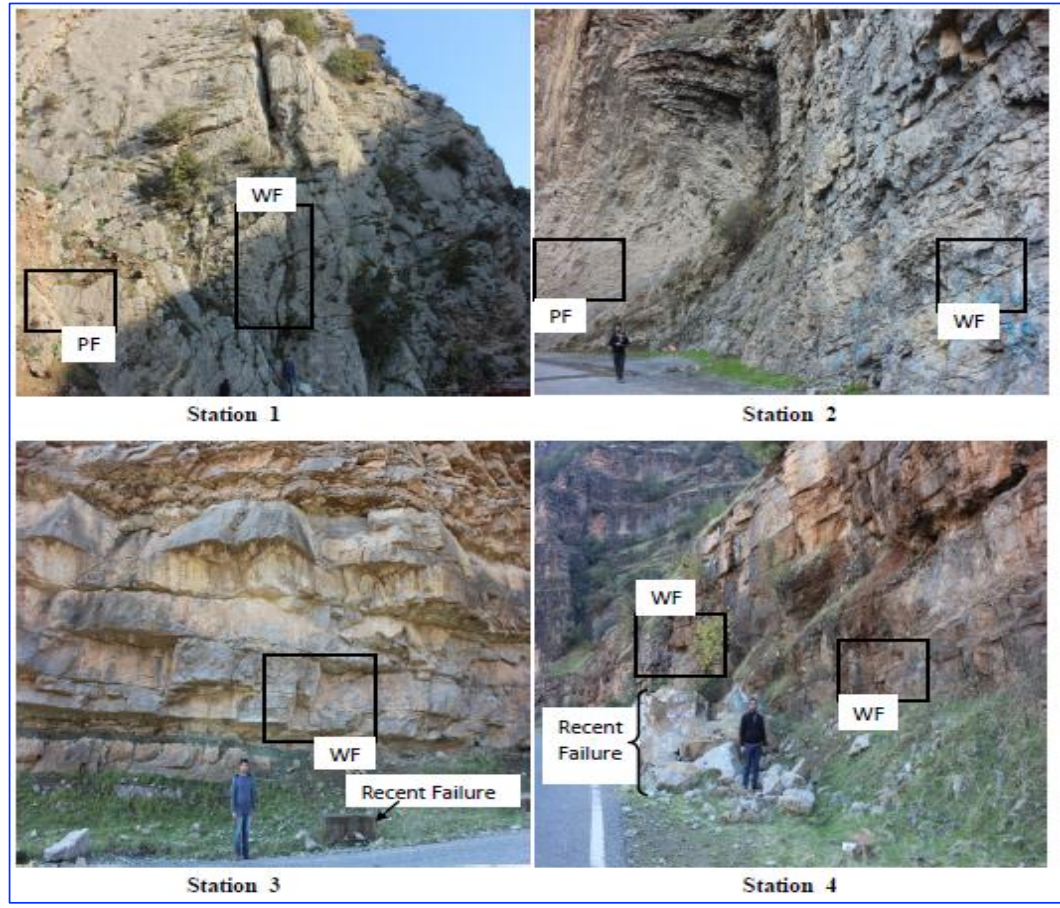

Fig. 3. The rock slopes in the stations $1,2,3$ and 4 with type of failure where; $W F=$ wedge failure and $P F=p l a n e$ failure in the SW limb of the Bradost Anticline
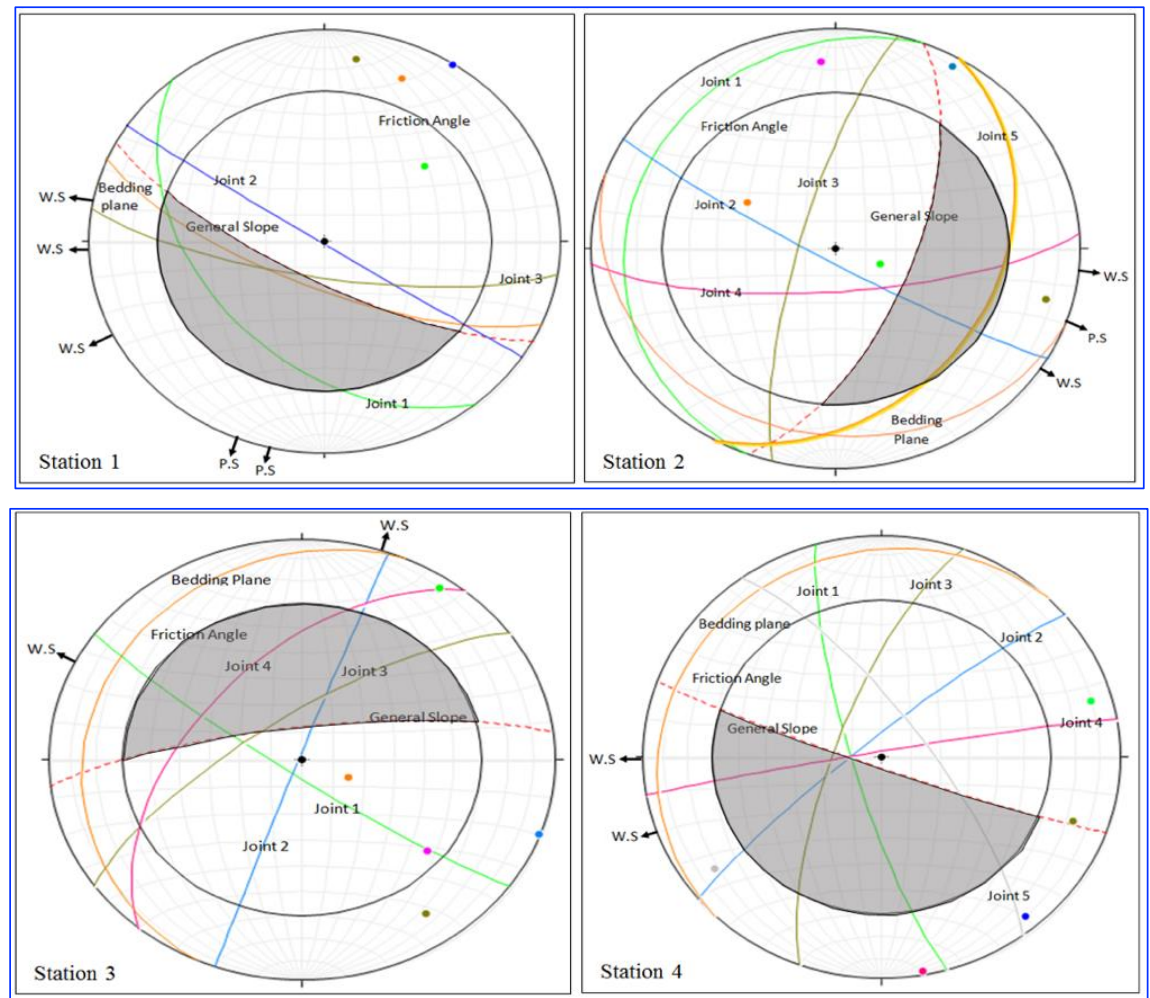

Fig. 4. Stereographic projection diagrams show the geometrical relation between the general slope, discontinuities and the direction of the probable type of failure, Where; W. S= direction of wedge sliding, P.S = direction of plane sliding and the area of potential sliding (shaded area) from station 1 to 4 in the SW limb of the Bradost Anticline 


\subsubsection{Station 6}

This station is located at the northeast limb on Korek Anticline at the Qamchuqa Formation with longitude: $44^{\circ} 26^{\prime} 19^{\prime \prime} \mathrm{E}$ and Latitude: $36^{\circ} 37^{\prime} 43^{\prime \prime} \mathrm{N}$ (Fig. 2). The field measurement for rock slope height, slope and discontinuities (bedding planes and joints) attitude demonstrated in Table 2. The slope and exposed layers orientation data determined that the slope is orthogonal, the slope is left emergent in laterality, moreover the slope has a concordance (Al-Saadi's, 1981). There is a one interested unstable rock block with $4 \mathrm{~m}$ width and $12 \mathrm{~m}$ length of dolomitic limestone with highly weathered. Sliding is likely to occur in this slab because it is unsupported at the toe of the slope and at the back there is a wide joint makes this block become potential rock sliding along the slope direction (Fig. 5). The unstable rock slope is light brown, fine grained, medium bedded, highly weathered and very strong dolomitic limestone. The wedge sliding is a failure type that occurs in this station at the intersection between (joint 2 and joint 4) because the plunge of the line of intersection is greater than the friction angle surface (Hoek and Bray, 1981; Hudson and Harrison, 1997; Norrish and Wyllie, 1996; Wyllie and Mah, 2004) (Fig. 6), in addition, after recording the data for this research the unstable rock block has slide to the road near the checkpoint in the Khalifan district.

\subsubsection{Station 7}

This station is located in the NW plunging area of the Korek Anticline at the Qamchuqa Formation with longitude: $44^{\circ} 29^{\prime} 12^{\prime \prime} \mathrm{E}$ and Latitude: $36^{\circ} 37^{\prime} 41^{\prime \prime} \mathrm{N}$ (Fig 2). Table 2 shows the rock slope height, slope and discontinuities (bedding planes and joints) attitude. According to slope and exposed layers orientation data the slope is orthogonal, but the slope is left emergent in laterality, moreover the slope has a discordant (Al-Saadi's, 1981). The interested in this station is a rock block with a dimension $6 \mathrm{~m}$ wide and $8 \mathrm{~m}$ length and eroded mostly from all sides. This layer is light yellowish, fine grained, medium bedded, highly weathered, moderately widely jointed and strong Limestone (Fig. 5). The probable type of failure is expected in this slab as a wedge sliding in the intersection between joint 4 and 2 and joint 3 and 2 because the line of intersection (daylight) to face slopes and it is steeper than the average friction angle of the plane (Hoek and Bray, 1981; Hudson and Harrison, 1997; Norrish and Wyllie, 1996; Wyllie and Mah, 2004) (Fig. 6).

\subsubsection{Station 8}

This station is located on the Korek Anticline in Bekhme Formation with longitude: $44^{\circ} 25^{\prime} 53^{\prime \prime}$ E and Latitude: $36^{\circ} 37^{\prime} 40^{\prime \prime} \mathrm{N}$ (Fig. 2). The rock slope height, slope and discontinuities (bedding planes and joints) attitude are illustrated in Table 2. According to slope and exposed layers orientation data the slope is oblique because the divergent angle is $31^{\circ}$, but the slope is left emergent in laterality, moreover the slope has a concordance (Al-Saadi's, 1981). The daylighting layer is $1.3 \mathrm{~m}$ thick. It is light yellowish to grey, fine grained, medium bedded, highly weathered, extremely closed jointed and very strong limestone. The limestone layer is cut by different discontinuities which are almost closed and whose average persistence is $5 \mathrm{~m}$. Sliding likely occur along the joints and the catchment area of the rock sliding is a toe of the slope (Fig. 5). Furthermore, The wedge sliding is a failure type that occurs in this station at the intersection between joint 1 and joint 2 and joint 3 and joint 2 because the plunge of the line of intersection is greater than the friction angle surface (Hoek and Bray, 1981; Hudson and Harrison, 1997; Norrish and Wyllie, 1996; Wyllie and Mah, 2004) (Fig. 6). The Fig. 5 at station 8 recorded the recent rock sliding in the toe of the slope. 


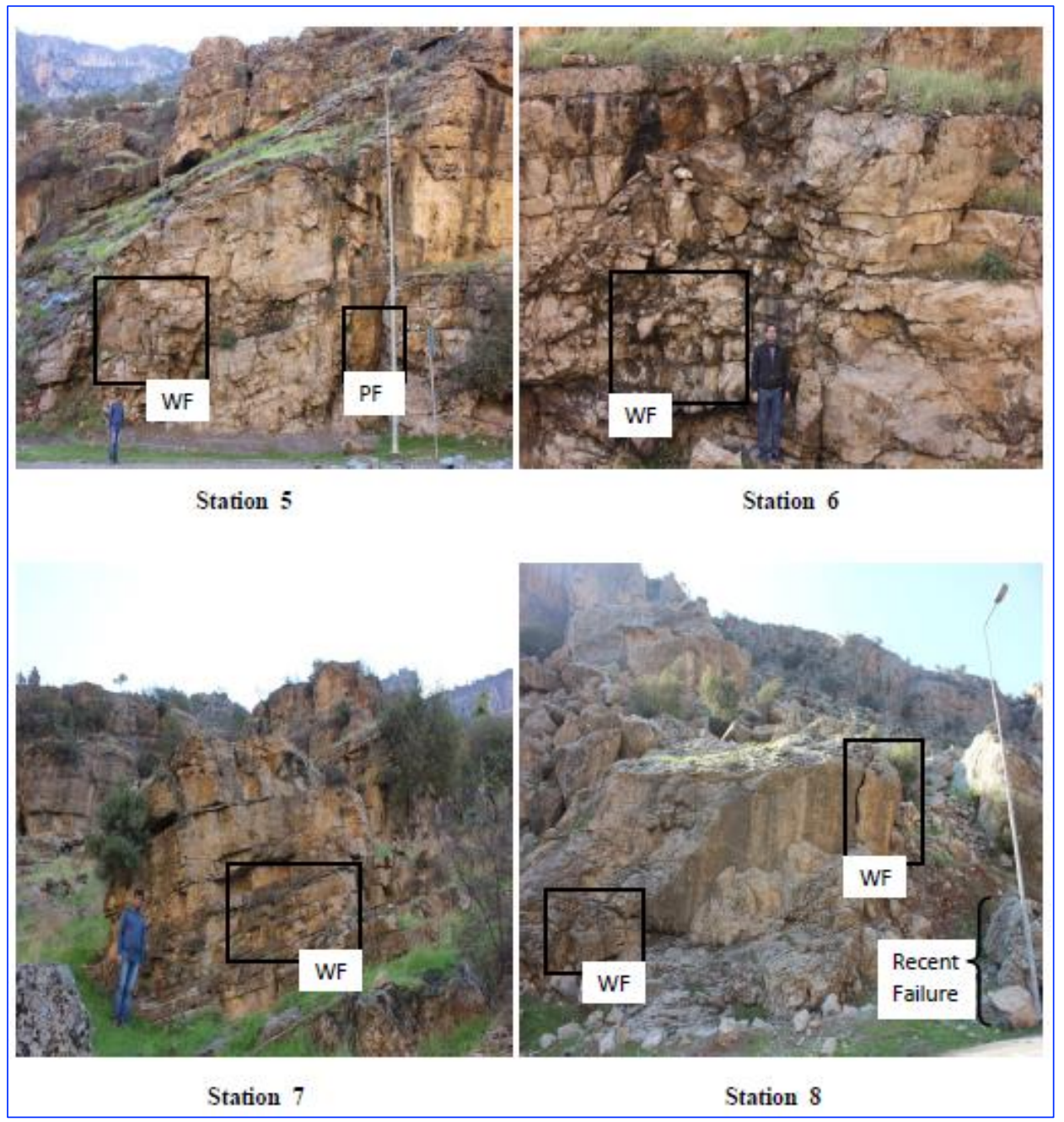

Fig. 5. The rock slopes in the stations 5, 6, 7 and 8 with type of failure where; WF is wedge failure and PF is plane failure in the Korek Anticline

\subsubsection{Station 9}

This station is located at the southwest limb of the Korek Anticline in Bekhme Formation and it has longitude: $44^{\circ} 25^{\prime} 53^{\prime \prime} \mathrm{E}$ and Latitude: $36^{\circ} 37^{\prime} 40^{\prime \prime} \mathrm{N}$ (Fig. 2). The collected data for rock slope height, slope and discontinuities (bedding planes and joints) attitude showing in Table 2. The slope and exposed layers orientation data identified that the slope is oblique, but the slope is left emergent in laterality, moreover the slope has a concordance (Al-Saadi's, 1981). The rock mass is yellowish to grey, fine grained, medium bedded, highly weathered, extremely closed jointed and very strong dolomitic limestone. The dolomitic limestone layer is cut by five discontinuities which are almost closed and whose average persistence is $2 \mathrm{~m}$ with a frequency $1-2 / \mathrm{m}$ (Fig. 7). The probable type of failure in this station is a wedge sliding in the intersection between joint 1 and 5 joint 4 and 5 and joint 3 and 5 due to the line of intersection (daylight) to face slopes and it is steeper than the average friction angle of the plane. Also, the plane sliding likely to occur within Joint 4 and 5 because the dip direction of the potential sliding plane is within $20^{\circ}$ of dip direction of slope face (Hoek and Bray, 1981; Hudson and Harrison, 1997; Norrish and Wyllie, 1996; Wyllie and Mah, 2004) (Fig. 8). In addition, the toe of the slope or the main Rawanduz road is a catchment area for rock sliding. 

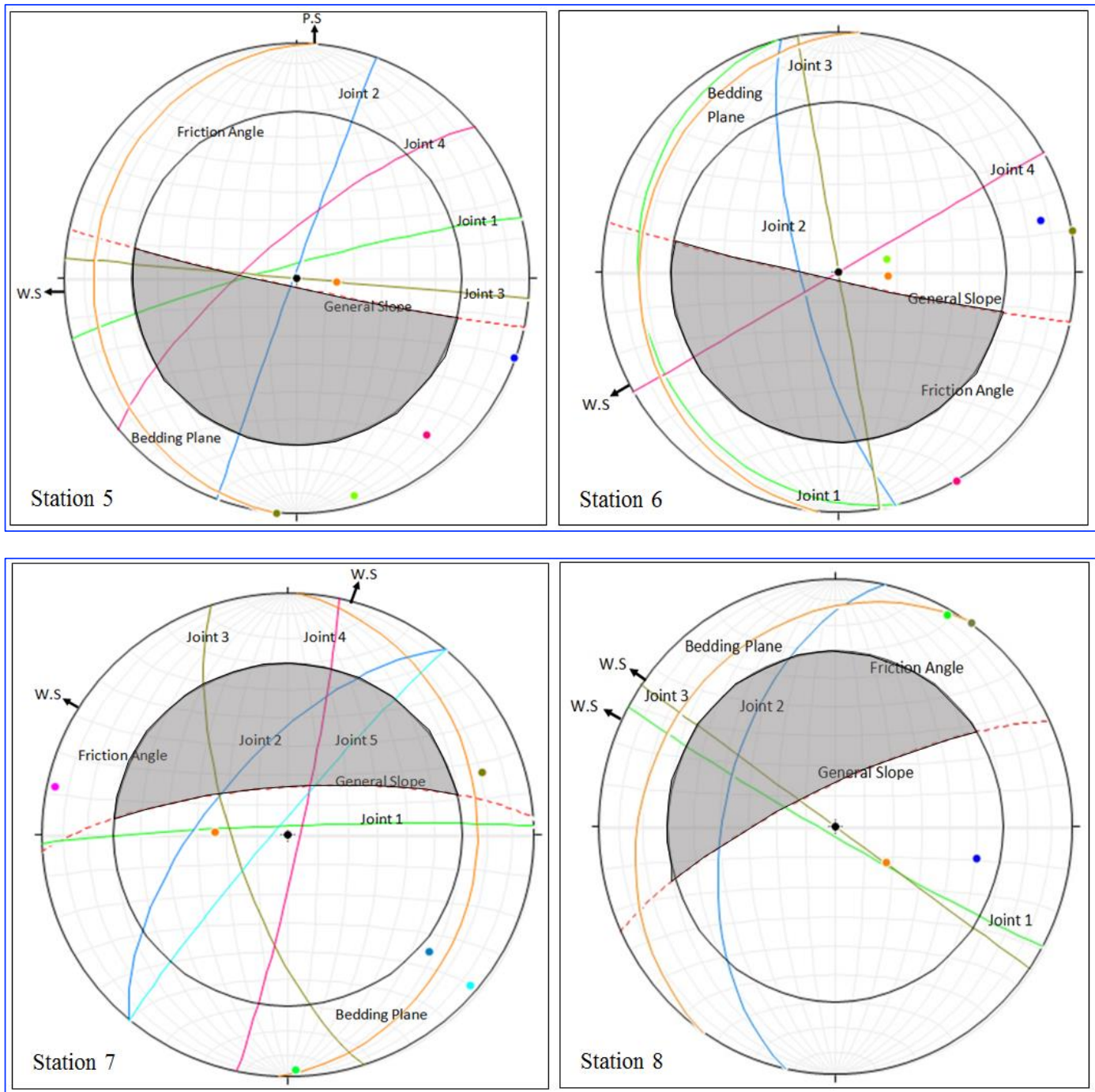

Fig. 6. Stereographic projection diagrams show the geometrical relation between the general slope, discontinuities and direction of the probable type of failure, Where; W. S is direction of wedge sliding, P.S is direction of plane sliding and the area of sliding (shaded area) from station 5 to 8 in the Korek Anticline

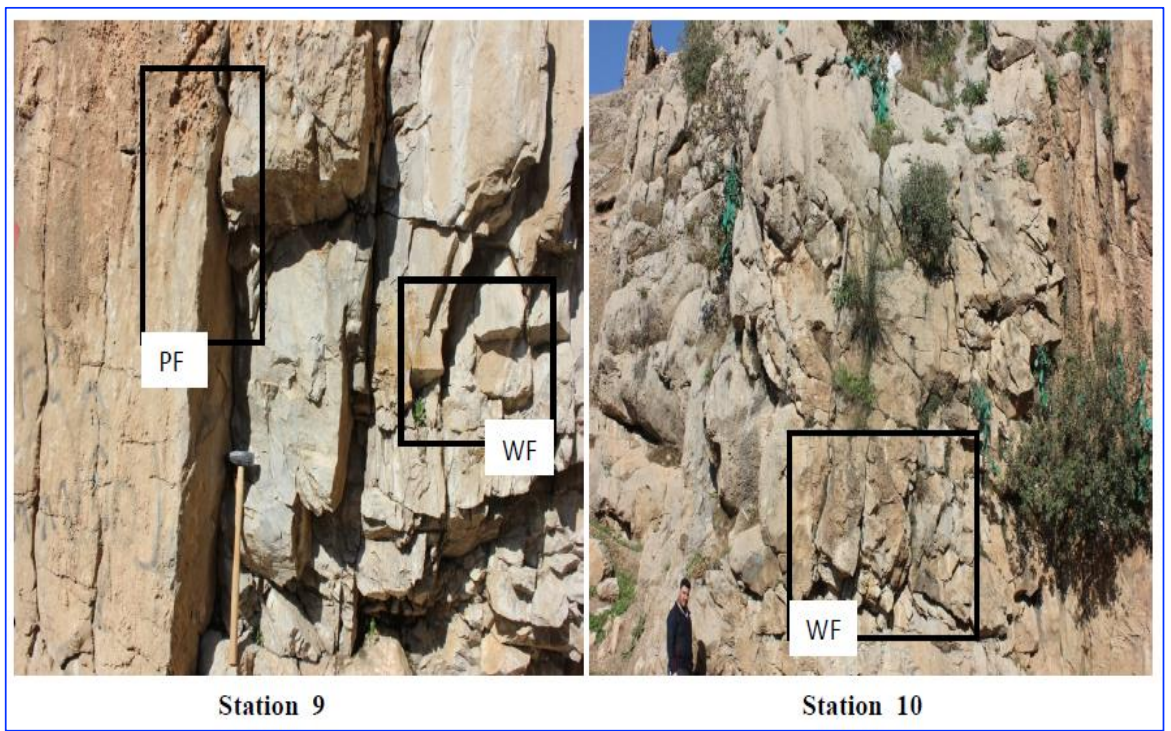

Fig. 7. The rock slopes in the stations 9 and 10 with type of failure where; WF is wedge failure and PF is plane failure in the SW limb of the Korek Anticline 


\subsubsection{Station 10}

This station is located at the southwest limb of the Korek Anticline in the Bekhme Formation it has longitude: $44^{\circ} 25^{\prime} 03^{\prime \prime} \mathrm{E}$ and Latitude: $36^{\circ} 37^{\prime} 07^{\prime \prime} \mathrm{N}$ (Fig 2). The site measurement for rock slope height, slope and discontinuities (bedding planes and joints) attitude shown in Table 2. The slope and exposed layers orientation data determined that the slope is orthogonal, but the slope is left emergent in laterality, moreover the slope has a discordant (Al-Saadi's, 1981). The interested of this site is an unstable rock slab with a dimension $4 \mathrm{~m}$ wide and $10 \mathrm{~m}$ long with yellowish to grey in colour, fine grained, medium bedded, highly weathered, closed jointed and very strong dolomitic limestone (Fig. 7). The dolomitic limestone layer is cut by three discontinuities which are almost closed and whose average persistence is $2 \mathrm{~m}$ with a frequency $3-4 / \mathrm{m}$. The probable type of failure in this station is a wedge sliding in the intersection between joint 2 and bedding plane because the line of intersection (daylight) to face slopes and it is steeper than the average friction angle of the plane (Hoek and Bray, 1981; Hudson and Harrison, 1997; Norrish and Wyllie, 1996; Wyllie and Mah, 2004) (Fig. 8).

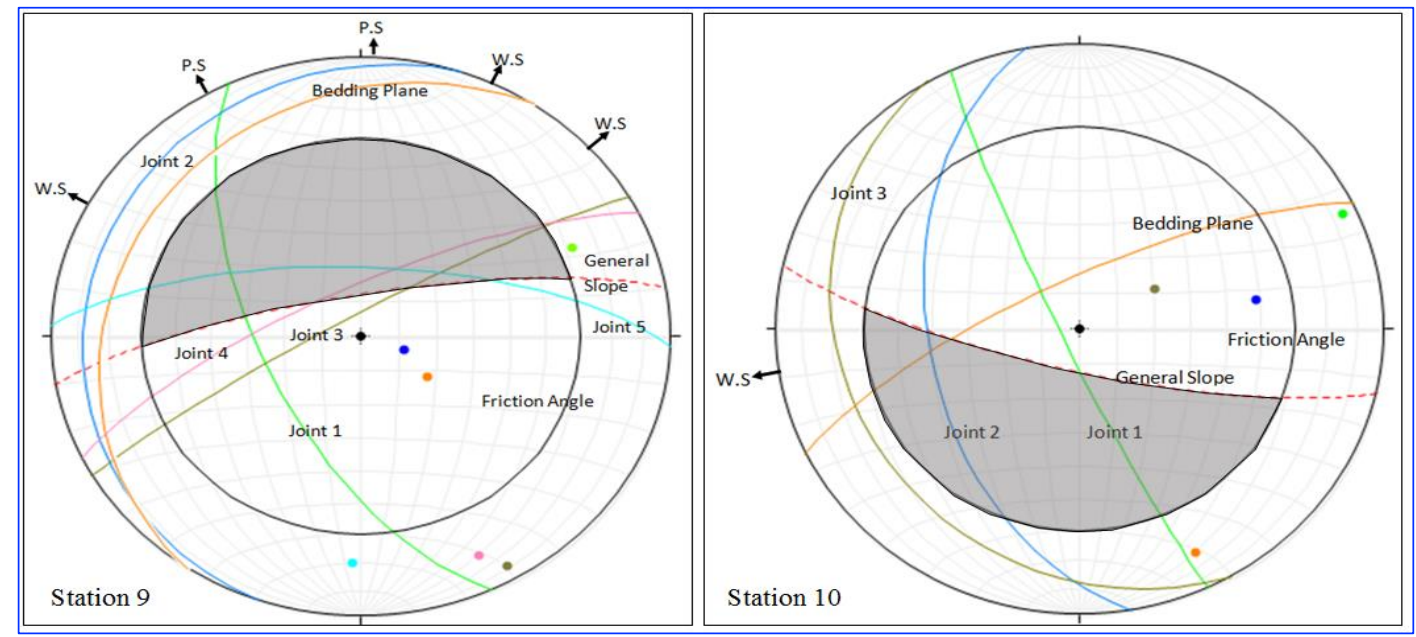

Fig. 8. Stereographic projection diagrams show the geometrical relation between the general slope, discontinuities and direction of the probable type of failure, Where W. S is direction of wedge sliding, P. S is direction of plane sliding and the area of potential sliding (shaded area) in station 9 and 10 in the SW limb of the Korek Anticline

\section{Conclusions and Recommendations}

The rock slope failure is mostly founded in the Southwest limb of Bradost anticline and Northeast to Southwest limb of the Korek Anticline along the Khalifan -Bekhal - Rawanduz main road. The rock slopes lithology is composed of dolomitic limestone and limestone along the road and that has made the probable type of failure, but in station 3 the thin bedded of marl interbedded with limestone determined. The point load test illustrated that the maximum compressive strength (356.1 MPa for limestone in station no. 2) and minimum compressive strength (59.12 MPa for dolomitic limestone in station no. 5). In addition, the rock slopes are mostly eroded and cut by different orientated discontinuities. Furthermore, the types of discontinuous play a significant role of the probable types of failure that occur in the study area. The wedge and plane failure are mainly inevitable to occur in the rock slopes along the road. Future sliding is expected in the study area, besides the recorded data showing the instability of the rock slope and their hazards in the study area, moreover, the remediation technique is required to minimize the hazard in the rock slopes because that leads to sliding. The main remediation technique proposed in the site is the removal of the unstable blocks of the limestone and dolomitic limestone in all stations, the trench at the toe of the slope face is an additional proposed remediation measure that preferred in the site to catch the unstable blocks in the station $(1,3,4,5,6,8,9$ and 10). In those stations, 
there is the possibility to apply, the rock bolt in station $(7,8$, and 9$)$ is necessary to stabilize the limestone and dolomitic limestone rock blocks, and removing the vegetation in the top slope face is required to reduce the hazards because this factor is favorable for sliding. To avoid future sliding in the study area the monitoring of rock slope behavior is recommended.

\section{Acknowledgements}

The authors are very grateful to the Editor in Chief Prof. Dr. Salih M. Awadh, the Secretary of Journal Mr. Samir R. Hijab. and the Technical Editors for their great efforts and valuable comments. Also, the authors need to express gratitude to Mr. Shevan Jirjess for aiding during the field work and laboratory work.

\section{References}

Allmendinger, R. W., Cardozo, N. C., Fisher, D., 2012, Structural Geology Algorithms: Vectors \& Tensors: Cambridge, England, Cambridge University Press, 289p.

Al-Saadi, S. N., Al-Jassar, S. H., 1993. Rock slides along Haibat Sultan Road, N. Iraq. International Conference on Case Histories in Geotechnical Engineering, 25p.

Al-Saadi, S., 1981. A Method for Mapping Unstable Slopes with Reference to the Coastline of S.W. Dyfed, Walse, Unpublished Ph.D. Thesis, University of Bristol, 252p.

Al-Shwaily, A. Kh., Al-Mosawi, H. A., Al-Saffi, I. K., Bashir, W. Ph., Ibrahim, A. A., Al-Jubouri, B. S., AlKubaisi, K. N., Mahmood, A. A., Al-Shawi, S. A., 2012. Semi detailed geological mapping of Sulaimaniyah - Surdash area. GEOSURV, Report, 3340.

Amer, R. M., 1993. Upper Cretaceous microfacies of Iraq. GEOSURV, Report, 2098.

Anon, 1972. The Preperation of Maps and Plans in Terms of Engineering Geology, QJEG 5, 293- 382.

Anon, 1977. The Description of Rock Masses for Engineering Purposes, QJEG 10, 355-388.

Balaki, H. G. K., Omar, A. A., 2019. Structural assessment of the Bradost and Berat structures in Imbricate and High Folded zones-Iraqi Kurdistan Zagros belt. Arabian Journal of Geosciences 12 (4), 106.

Bruce, I. G., Cruden, D. M., Eaton, T. M., 1989. Use of a tilting table to determine the basic friction angle of hard rock samples. Canadian Geotechnical Journal 26 (3), 474-479.

Buday, T., 1980. The Regional Geology of Iraq, Stratigraphy and Paleogeography, Dar AL-Kuttib Pub. House. University of Mosul, Iraq. 445.

Buday, T., and Jassim, S. Z., 1987. The Regional Geology of Iraq (Tectonism, Magmatism and Metamorphism). Kassab, I. I., and Abbas, M. J., Baghdad, Iraq: Geological Survey Mining, 352p.

Fouad, S. F., 2010. Tectonic and structural evolution of the Mesopotamia Foredeep, Iraq. Iraqi Bulletin of Geology and Mining 6 (2), 41-53.

Hawkins, A. B., 1986. Rock description, geological society, engineering geology, Special Publication 2, 59-72.

Hencher, S. R., and Richards, L. R., 1982. The basic frictional resistance of sheeting joints in Hong Kong granite. Hong Kong Engineer 11 (2), 21-25.

Hoek, E., and Bray J., W., 1981. Rock Slope Engineering, third ed., Institution of Mining and Metallurgy, London. UK.

Hudson, J. A., and Harrison, J. P., 1997. Engineering rock mechanics, an introduction to the principles. Elsevier science Ltd, Oxford, UK.

ISRM, 1985. Suggested method for determining point load strength, In International Journal of Rock Mechanic and Mining Science and Geomechanics Abstracts 22 (2), 53-60.

Jassim, S. Z., and Goff, J. C., 2006. Geology of Iraq. Dolin, Prague and Moravian Museum, Brno, 341p.

Jassim, S. Z., and Buday, T., 2006. Tectonic framework. Geology of Iraq. Czech Republic: Published by Dolin, Prague and Moravian Museum, Brno, 35-52p.

Jassim, S. Z., Karim, S. A., Basi, M. A., Al-Mubarak, M., Munir, J., 1984. Final report on the regional geological survey of Iraq, Vol. 3, Stratigraphy. GEOSURV, Report, 1447.

Karim, K. H., Khanaqa, P.A., 2016. Lithology and stratigraphy of the Cenomanian/Turonian boundary in Zagroz orogenic belt examples from Kurdistan Region, Northeastern Iraq. Iraqi Geological Journal 39-49 (2), 73 90 . 
Mamaseni, W. J., Naqshabandi, S. F., Al-Jaboury, F. K., 2019. Palynofacies and paleoenvironment of late JurassicEarly Cretaceous Formation at Duhok basin, Northern Iraq. Iraqi Geological Journal 52 (1), 61-82.

Mouthereau, F., Lacombe, O., Vergés, J., 2012. Building the Zagros collisional orogen: Timing, strain distribution and the dynamics of Arabia/Eurasia plate convergence, Tectonophysics 532, 27-60.

Norrish, N. I. and Wyllie, D. C., 1996. Stabilization of rock slopes. In special report 247: Landslides, Investigation and Mitigation, eds. A. K. Turner and R.L. Schuster, Transportation Research Board, National Research Council, National Academy Press, Washington, DC 18, 391- 504.

Omar, A. A., 2005. An integrated structural and tectonic study of the Bina Bawi-Safin Bradost Region: Unpublished Ph.D. thesis, Salahaddin University, Erbil. 300p.

Omar, A. A., Othman A. T., 2018. Morpho-structural study of the Korek Anticline, Zagros Fold-Thrust Belt, Kurdistan of Iraq, Geotectonics 52 (3), 382-400.

Sharland, P. R., Archer, R., Casey, D.M., Davies, R. B., Hall, S. H., Heward, A. P., Horbury, A. D. Simmons, M. D., 2001. Sequence stratigraphy of the Arabian Plate. Geo Arabia, 2 (37), 1.

Sissakian, V. K., Al-Jiburi, B. S., 2014. Stratigraphy of the high folded zone. Iraqi Bulletin of Geology and Mining 6, 73-161.

Sissakian, V. K., and Youkhanna, R.Y., 1979. Report on the regional geological mapping of Erbil- Shaqlawa -Koi Sanjaq -Raidar Area. GEOSURV, Report, 975.

Wyllie, D.C., Mah, C.W., 2004. Rock slope engineering: civil and mining, fourth ed. Based on the third edition by E., Hoek and J. Bray. Spon Press, Taylor and Francis Group, London and New York. 